\title{
Systemic Mastocytosis with Associated Chronic Lymphocytic Leukemia: A Matter of Diseases or Prognostic Factors?
}

\author{
Kronik Lenfositik Lösemi ile Birlikte Seyreden Sistemik Mastositoz: Hastalık Nedeni ile mi \\ Prognostik Etki mi?
}

Antonella Zagaria, Luisa Anelli, Nicoletta Coccaro, Giuseppina Tota, Claudia Brunetti, Angela Minervini, Paola Casieri, Luciana Impera, Crescenzio Francesco Minervini, Annamaria Giordano, Paola Orsini, Cosimo Cumbo, Giorgina Specchia, Francesco Albano

Bari University Faculty of Medicine, Department of Emergency and Organ Transplantation, Bari, Italy

\section{To the Editor,}

Systemic mastocytosis (SM) is a clonal disorder characterized by the accumulation of abnormal mast cells in various tissues and by a broad range of diseases, ranging from indolent to advanced systemic pathology. In 2016, the World Health Organization revised the SM classification into seven distinct variants [1]; among them is SM with an associated hematological neoplasm (SM-AHN), accounting for approximately $40 \%$ of all SM cases [2]. Usually the AHN is an aggressive neoplasm that can be challenging to diagnose either because the mast cell infiltrate can be subtle and difficult to identify or because the mast cell infiltrate can be prominent, thus obscuring the underlying AHN. Frequently the AHN is represented by a myeloid neoplasm, whereas the observation of an association between SM and lymphoproliferative diseases is uncommon. In particular, chronic lymphocytic leukemia (CLL) in the context of SM-AHN has been rarely reported $[2,3,4,5,6]$ (Table 1). Here, we describe a new case of SM with associated CLL, in which the cytological features of the two neoplasias were evident in bone marrow aspirate; moreover, in this case molecular analysis specific for SM was performed.

A 65-year-old female patient presented with lymphocytosis (leukocytes, $66 \times 10^{9}$ cells/L; lymphocyte absolute count, $63 \times 10^{9}$ cells $/ \mathrm{L}$; hemoglobin level, $12.1 \mathrm{~g} / \mathrm{dL}$; platelets,
$243 \times 10^{9}$ cells/L). Physical examination revealed no abnormalities. Peripheral blood smear analysis demonstrated the presence of $\sim 90 \%$ small mature lymphocytes together with smear cells (Gumprecht shadows). Flow cytometry analysis of the lymphocyte population showed positive staining for anti-CD5, CD19, CD23, and CD20 antibodies and a k-type light chain restriction. The bone marrow aspirate appeared hypercellular due to the infiltration of lymphoid cells, which were morphologically similar to those in the peripheral blood and accounted for at least 70\% of all nucleated marrow cells. Moreover, morphologic analysis showed the presence of at least 10\% of mast cells, mainly characterized by a fusiform cytoplasm (Figure 1). Bone marrow biopsy confirmed the lymphocyte infiltration associated with the presence of atypical mast cells (CD117 ${ }^{+}$, tryptase $\left.{ }^{+}, \mathrm{CD} 2^{+}, \mathrm{CD} 25^{+}\right)$; multifocal mast cell aggregates ( $>15$ mast cells) were frequently observed in perivascular and paratrabecular bone marrow locations. The tryptase level was $64.5 \mathrm{ng} / \mathrm{mL}$. Total body computed tomography revealed no abnormalities. Conventional cytogenetics showed a normal karyotype, i.e. 46,XX [20], whereas fluorescent in situ hybridization, performed with probes specific for chromosomal aberrations associated with CLL, revealed the presence of del(13) (q14) and no alterations at the 17p13, 11q22, and 12q13 loci. $I G V H$ was not mutated. Molecular analysis revealed the KIT D816V mutation, whereas SRSF2, ASXL1, and JAK2 V617F were

\begin{tabular}{|l|l|l|l|l|l|}
\hline \multicolumn{6}{|l|}{ Table 1. Main characteristics of prior reported SM-CLL cases. } \\
\hline Sex/Age & KIT D816V & Karyotype & Treatment & Outcome & Reference \\
\hline NR & NR & Normal & None & NR & {$[2]$} \\
\hline NR & NR & $\begin{array}{l}\text { del(11)(q14) } \\
\text { del(13)(q14) }\end{array}$ & None & NR & {$[2]$} \\
\hline Female/56 & - & del(13)(q14) & FCR + MUD AHSCT & CLL in CR & {$[3]$} \\
\hline & & & & SM persistence & \\
\hline Male/48 & - & del(11)(q14) & FCR + alemtuzumab & CLL in CR & {$[4]$} \\
\hline & & & Imatinib & SM persistence & \\
\hline Male/36 & NR & NR & None & SM and CLL stable 12 months after the diagnosis & {$[5]$} \\
\hline Female/69 & + & NR & NR & NR & {$[6]$} \\
\hline $\begin{array}{l}\text { NR: Not reported, FCR: fludarabine, cyclophosphamide, rituximab; MUD AHSCT: matched unrelated donor allogeneic hematopoietic stem cell transplantation, CR: complete remission, } \\
\text { CLL: chronic lymphocytic leukemia, SM: systemic mastocytosis. }\end{array}$ \\
\hline
\end{tabular}



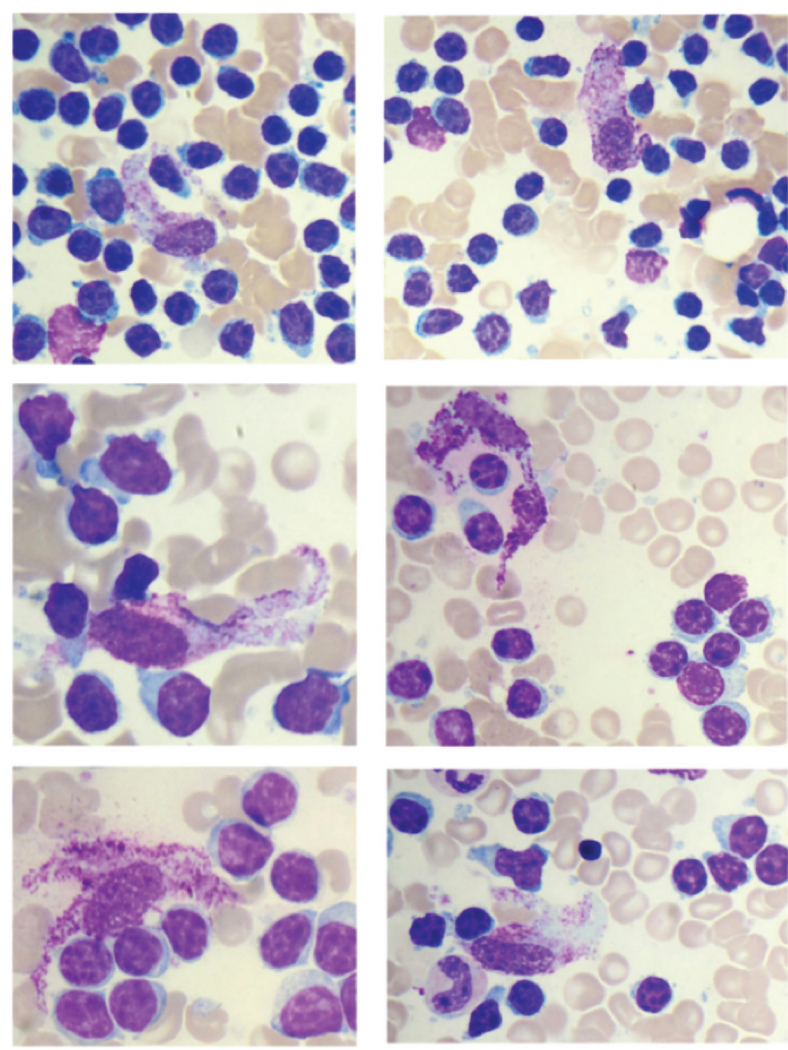

Figure 1. Systemic mastocytosis with an associated hematological neoplasm bone marrow aspirate. Atypical mastocytes with spindle nucleus and granules spread throughout the plentiful basophilic cytoplasm. The mastocytes are located in the context of bone marrow rich in mature lymphocytes.

not altered. Based upon these findings, the patient was diagnosed with SM (the major criterion and 3 minor criteria) with associated CLL (Rai 0, Binet A stage). Since neither of the two diseases showed signs of activity it was decided to choose a "watch and wait" strategy, and 1 year after the diagnosis the SM-AHN remains stable (lymphocyte absolute count, $92 \times 10^{9}$ cells/L; tryptase level, $67 \mathrm{ng} / \mathrm{mL}$ ) and the patient is doing well. Reportedly, SM-AHN has a poor prognosis with a median survival of less than 2-4 years [7]. Given the low frequency of CLL in the context of SM-AHN, it is very difficult to draw general prognostic considerations for this entity, but recently it was published that advanced SM patients bearing SRSF2 and/or ASXL1 mutations have a poor prognosis $[8,9]$. Note that among the SM patients reported in those two studies there was not a case associated with CLL. In conclusion, we suggest that the stable course of SM-AHN may derive from the concurrence of the positive prognostic factors that characterize the two diseases in our patient.

\section{Acknowledgment}

This work was supported by "Associazione Italiana Contro Le Leucemie (Ail)-Bari".

Keywords: Systemic mastocytosis, Systemic mastocytosis with an associated hematological neoplasm, Chronic lymphocytic leukemia, KIT D816V

Anahtar Sözcükler: Sistemik mastositoz, Hematolojik malignite ile seyreden sistemik mastositozis, Kronik lenfositik lösemi, KIT D816V

Conflict of Interest: The authors of this paper have no conflicts of interest, including specific financial interests, relationships, and/or affiliations relevant to the subject matter or materials included.

\section{References}

1. Arber DA, Orazi A, Hasserjian R, Thiele J, Borowitz MJ, Le Beau MM, Bloomfield CD, Cazzola M, Vardiman JW. The 2016 revision to the World Health Organization classification of myeloid neoplasms and acute leukemia. Blood 2016;127:2391-2405.

2. Wang SA, Hutchinson L, Tang G, Chen SS, Miron PM, Huh YO, Jones DM, Bueso-Ramos C, Verstovsek S, Medeiros $\sqcup$, Miranda RN. Systemic mastocytosis with associated clonal hematological non-mast cell lineage disease: clinical significance and comparison of chromosomal abnormalities in SM and AHNMD components. Am J Hematol 2013;88:219-224.

3. Du S, Rashidi HH, Le DT, Kipps TJ, Broome HE, Wang HY. Systemic mastocytosis in association with chronic lymphocytic leukemia and plasma cell myeloma. Int J Clin Exp Pathol 2010;3:448-457.

4. Ault P, Lynn A, Tam CS, Medeiros $\amalg$, Keating MJ. Systemic mastocytosis in association with chronic lymphocytic leukemia: a rare diagnosis. Leuk Res 2007;31:1755-1758.

5. Sanz MA, Valcárcel D, Sureda A, Muñoz L, Espinosa I, Nomdedeu J, Sierra J. Systemic mast cell disease associated with B-chronic lymphocytic leukemia. Haematologica 2001;86:1106-1107.

6. Horny HP, Sotlar K, Stellmacher F, Valent P, Grabbe J. An unusual case of systemic mastocytosis associated with chronic lymphocytic leukaemia (SMCLL). J Clin Pathol 2006;59:264-268.

7. Pardanani A. Systemic mastocytosis in adults: 2017 update on diagnosis, risk stratification and management. Am J Hematol 2017;91:1146-1159.

8. Jawhar M, Schwaab J, Hausmann D, Clemens J, Naumann N, Henzler T, Horny HP, Sotlar K, Schoenberg SO, Cross NC, Fabarius A, Hofmann WK, Valent P, Metzgeroth G, Reiter A. Splenomegaly, elevated alkaline phosphatase and mutations in the SRSF2/ASXL1/RUNX1 gene panel are strong adverse prognostic markers in patients with systemic mastocytosis. Leukemia 2016;30:2342-2350.

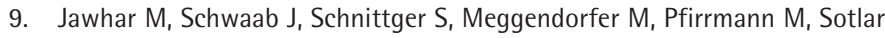
K, Horny HP, Metzgeroth G, Kluger S, Naumann N, Haferlach C, Haferlach T, Valent $\mathrm{P}$, Hofmann WK, Fabarius A, Cross NC, Reiter A. Additional mutations in SRSF2, ASXL1 and/or RUNX1 identify a high-risk group of patients with KIT D816V+ advanced systemic mastocytosis. Leukemia 2016;30:136-143. 